\title{
Anti-Cancer Effects of Imperata cylindrica Leaf Extract on Human Oral Squamous Carcinoma cell line SCC-9 in Vitro
}

\author{
Rohini Keshava ${ }^{1 *}$,Nagesh Muniyappa ${ }^{2}$, Rajalakshmi Gope ${ }^{3}$,Ananthanarayana \\ Saligrama Ramaswamaiah ${ }^{1}$
}

\begin{abstract}
Imperata cylindrica, a tall tufted grass which has multiple pharmacological applications is one of the key ingredients in various traditional medicinal formula used in India. Previous reports have shown that $I$. cylindrica plant extract inhibited cell proliferation and induced apoptosis in various cancer cell lines. To our knowledge, no studies have been published on the effect of $I$. cylindrica leaf extract on human oral cancers. The present study was undertaken in order to evaluate the anticancer properties of the leaf extract of $I$. cylindrica using an oral squamous cell carcinoma cell line SCC-9 as an in vitro model system. A methanol extract from dried leaves of $I$. cylindrica (ICL) was prepared by standard procedures. Effects of the ICL extract on the morphology of SCC-9 cells was visualized by microscopy. Cytotoxicity was determined by MTT assay. Effects of the ICL extract on colony forming ability of SCC-9 cells was evaluated using clonogenic assay. Cell cycle analysis was performed by flow cytometry and induction of apoptosis was determined by DNA fragmentation assay. The ICL extract treatment caused cytotoxicity and induced cell death in vitro in SCC-9 cells in a dose-dependent manner. This treatment also significantly reduced the clonogenic potential and inhibited cell proliferation by arresting the cell cycle in the G2/M phase. Furthermore, DNA fragmentation assays showed that the observed cell death was caused by apoptosis. This is the first report showing the anticancer activity of the methanol extracts from the leaves of I. cylindrica in human oral cancer cell line. Our data indicates that ICL extract could be considered as one of the lead compounds for the formulation of anticancer therapeutic agents to treat/manage human oral cancers. The natural abundance of $I$. cylindrica and its wide geographic distribution could render it one of the primary resource materials for preparation of anticancer therapeutic agents.
\end{abstract}

Keywords: Oral cancer - SCC-9 cells - Imperata cylindrica - cell cycle arrest - apoptosis - DNA fragmentation

Asian Pac J Cancer Prev, 17 (4), 1891-1898

\section{Introduction}

Oral cell carcinoma belongs to the group of human head and neck cancers which causes high morbidity and mortality. In the year 2012 alone globally the oral cancers were estimated to have a fresh incidence and mortality of 300,373 and 145,353 respectively. The estimated prevalence for the year 2015 was 324,398 cases of incidence and 157,139 cases of deaths due to oral cancer (Ferlay et al., 2013; Forman et al., 2014). India has the highest incidences of oral cancer, 20 per every 100,000 population and it accounts for $30 \%$ of all cancers in this country (More and D'Cruz, 2013). The most common form of oral cancer is the squamous cell carcinoma which accounts for about $90 \%$ of all oral cancers (Ferlay et al., 2013; Krishna et al., 2013).

Many key risk factors have been identified for the susceptibility to oral cancer such as use of tobacco, consumption of alcohol, infection with human papilloma virus (HPV), malnutrition, vitamin deficiency and, poor dental and oral hygiene. In addition, the incidence of oral cancer is further increased due to the high usage of chewable/smokeless tobacco and betel quid in India (de Camargo Cancela et al., 2010; IARC, 2012; Anantharaman et al., 2013; Krishna et al., 2013). Data from the National Cancer Registry in India shows a gender based difference in oral cancer incidence with a men:women ratio of $2: 1$ which is suggestive of lifestyle and behavioral differences among genders (Sankaranarayanan et al., 2005; Thorat et al., 2009).

In developed countries the highest incidence of oral cancer was found in individuals who belong to the age group of 55 to 64 years. However, in the Southeast Asian countries, especially in India, Sri Lanka, Pakistan and Bangladesh, the affected individuals were below 40 years of age and it was attributed mainly to the higher rate of tobacco usage (More and D'Cruz, 2013). During the years 2001 to 2003 the age-specific oral cancer mortality 
rate in India for individuals between the age of 30 to 69 years was $22.9 \%$, which is twice as much as compared to the mortality rate of $11.4 \%$ for lung cancer (Dikshit et al., 2012).

Even though the conventional cancer treatments such as surgery, chemotherapy and radiation therapy are beneficial to some extent, often times they also exert severe, toxic side effects that affect patients' quality of life post treatments (Qi et al., 2010). In addition, emergence of resistant cancer cells post therapeutic interventions has prompted a critical need for the development of alternative approaches to treat/manage these cancers (Saraswathy and Gong, 2013). In this regard use of phytochemical agents have emerged as a lead alternative as they possess proven effective anticancer activity with minimal/no adverse side effects (Fulda, 2010). Several compounds such as vinca alkaloids, taxanes, camptothecin etc., with effective anticancer activity have been purified from many natural resources. Notably, more than $60 \%$ of all approved new anticancer drugs within the past decade are of phytochemical origin (Newman and Cragg, 2007; Fulda, 2010).

The grass, Imperata cylindrica (L.) Raeusch. (Poaceace), is known as Thatch grass or Cogon grass in English and Darbh in Hindi in India (Jayalakshmi et al 2010; Parvathy et al., 2012). It is a perennial, erect, tall tufted grass and it has a wide distribution throughout the Indian subcontinent, tropics and sub tropics of Africa, South-East Asia and Australia (Jayalakshmi et al, 2010; Parvathy et al, 2012). I. cylindrica has been known to have several medicinal applications as mentioned in the Ayurvedic Pharmacopoeia of India, 2006. In Indian traditional medicine, it is known to be used as a diuretic and an anti-inflammatory agent (Khare, 2007). Its diuretic properties have been reported by Doan et al., 1992 and Shah et al., 2012. In addition, it is reported to possess immunomodulatory (Pinilla and Luu, 1999) as well as neuroprotective (Yoon et al., 2006) activities. I. cylindrica is one of the important herbs used in ayurvedic formulations possessing significant antioxidant activities (Sushama and Nishteswar, 2014; Pragya et.al., 2015). A study conducted on an ayurvedic formulation consisting of I. cylindrica as one of the constituents has shown a possible potential as an adjuvant in cancer radiotherapy to produce beneficial results (Guruprasad et al., 2010).

Previous reports have shown that $I$. cylindrica plant extract inhibited cell proliferation and induced apoptosis in various cancer cell lines (Kuete et al., 2011; Kuete et al., 2013). To our knowledge, so far, no studies have been published on the effect of I. cylindrica leaf extract on human oral cancers. Therefore, the present study was undertaken in order to evaluate the anticancer properties of the leaf extract of I. cylindrica (ICL) using an established oral squamous cell carcinoma cell line SCC-9 as an in vitro model system.

\section{Materials and Methods}

\section{Materials and reagents}

Tris-HCl, $\mathrm{NaCl}$, EDTA, SDS, Triton X-100, dimethyl sulfoxide (DMSO), formaldehyde and, DNase free-
RNase-A were purchased from Merck Co. Mumbai, India. Propidium iodide (PI) was obtained from Beckton Dickinson, Gurgaon, Haryana, India. Dulbecco's Modified Eagles Medium (DMEM), fetal bovine serum (FBS), penicillin-streptomycin and trypsin-EDTA were purchased from Gibco BRL (Life technologies, Grand Island, NY, USA). 3-(4, 5-Dimethylthiazol-2-yl)-2,5Diphenyltetrazolium Bromide (MTT) reagent was obtained from Sisco Research Laboratories Pvt. Ltd., Mumbai, India. Crystal violet and proteinase $\mathrm{K}$ were obtained from Hi-Media, Mumbai, India. Hind III digest $\lambda$ DNA (catalogue number D-4521) was obtained from Sigma -Aldrich, St. Louis, MO, USA.

\section{Plant material collection and preparation of methanol} extracts

The Imperata cylindrica plant was collected from areas around Hassan township, Hassan district in the state of Karnataka, India. The herbarium specimen was authenticated at the botanical garden, University of Agricultural Sciences, G.K.V.K campus, Bangalore, Karnataka, India. A voucher specimen (Collection number - RKDSKPDF01; accession number - UASB3843) has been deposited at the herbarium. Freshly procured $I$. cylindrica leaves were surface sterilized with $70 \%$ ethanol, air dried in shade and pulverized using a commercial waring blender. Methanol extract was prepared by treating $10 \mathrm{~g}$ of leaf powder with $100 \mathrm{ml}$ methanol (100\%) in soxhlet apparatus (Vasa Scientific Co., Bangalore, India) at $60^{\circ} \mathrm{C}$ for $8 \mathrm{~h}$ (Harborne, 1998). The crude extracts were filtered using Whatman No.1 filter paper (Merck Co. Mumbai, India.) and concentrated using a rotary evaporator (Rotavapor R-100, BUCHI India Pvt. Ltd., Mumbai, India).Stock solution was prepared by dissolving the dried residue in appropriate volume of $100 \%$ dimethyl sulfoxide (DMSO) to get a final concentration of $64 \mathrm{mg} /$ $\mathrm{ml}$, from which required dilutions were prepared.

\section{Cell lines and culture conditions}

Human tongue squamous cell carcinoma, SCC-9 (ATCC CRL-1629), and NIH/3T3 (ATCC CRL-1658) mouse embryonic fibroblast cell lines were obtained from American Type Culture Collection (ATCC, Manassas, VA, USA) and maintained as recommended by the supplier. The SCC-9 and NIH/3T3 cells were grown in DMEM medium supplemented with $2.5 \mathrm{mM}$ L-glutamine, $15 \mathrm{mM}$ HEPES, and $10 \%$ FBS, along with $100 \mathrm{U} / \mathrm{ml}$ penicillin and $100 \mu \mathrm{g} / \mathrm{ml}$ streptomycin. These cells were maintained at $37^{\circ} \mathrm{C}$ in a humidified incubator under $95 \%$ air atmosphere plus $5 \% \mathrm{CO}_{2}$.

\section{Treatment with ICL extract}

All the experiments were done in triplicate in order to obtain statistically significant data. The ICL extracts were diluted with culture medium to give serial concentrations prior to application to the cells. The control cells were treated with media containing $1 \%$ DMSO.

Morphological assessment of SCC-9 cells treated with ICL extract

The effect of ICL extract on SCC-9 cell morphology 
were assessed by light microscopy. The SCC- 9 cells were seeded at a density of $5 \times 10^{4}$ cells/well in a 96-well cell culture plate and treated with various concentrations of 0 to $640 \mu \mathrm{g} / \mathrm{ml}$ of the ICL extract for $24 \mathrm{~h}$. NIH/3T3 mouse embryo fibroblast cells were used as an additional control. Changes in the cell morphology, if any, between the control and the ICL extract treated cells were monitored using a light microscope (Magnus 11D475, New Delhi, India) and documented by photography.

\section{Cytotoxicity analysis by MTT assay}

The SCC-9 cells and NIH/3T3 cells were seeded in a sterile flat bottom 96 -well plate at a density of $5 \times 10^{4}$ cells per well and incubated for $24 \mathrm{~h}$ in the culture conditions described were section 2.3 of Materials and Methods. Twenty four hours post seeding these cells were treated with ICL extracts to final concentrations of 10, 20,40, 80, 160,320 and $640 \mu \mathrm{g} / \mathrm{ml}$. The control cells were treated with media containing $1 \%$ DMSO. Twenty four hour post treatment with ICL extracts the culture media were replaced with $100 \mu 1$ of MTT reagent at a concentration of $0.5 \mathrm{mg} / \mathrm{ml}$ and incubated for $4 \mathrm{~h}$ at $37^{\circ} \mathrm{C}$ in dark. Then the MTT reagent was removed and the formazan crystals when present were solubilized in $100 \mu \mathrm{l}$ of DMSO with gentle shaking and incubated for an additional 15 minutes at room temperature in dark (Mosmann, 1983). The absorbance of the ICL extract treated samples and the control vehicle treated samples from each well was measured at $590 \mathrm{~nm}$ using a microtiter plate reader (TECAN Spectra Fluor plus, MTX Lab Systems, Inc., VA, U.S.A.). The cytotoxicity was calculated according to the protocol supplied by the manufacturer and it was expressed as percentage of growth inhibition in the ICL treated cells as compared to the vehicle treated control cells. The percentage growth inhibition was calculated using the following formula:

Percentage inhibition of cell proliferation $=[$ (Absorbance of vehicle treated control group-Absorbance of ICL treated experimental group) / (Absorbance of vehicle treated control group)] x 100 .

\section{Estimation of ICL treated and vehicle treated SCC-9 cells at various stages of cell cycle}

Approximately $1 \times 10^{6}$ SCC- 9 cells were cultured in a 6-well plate containing $2 \mathrm{ml}$ of complete DMEM plus $10 \%$ FBS and incubated as described section 2.3 of Materials and Methods. Approximately $32 \mathrm{~h}$ later the media was replaced with DMEM containing $1 \%$ serum and incubated for an additional $32 \mathrm{~h}$ in order to synchronise the cell cycle by serum starvation (Chen et al., 2012). After the cell cycle synchronisation, a final concentration of $80,160,320$ and $640 \mu \mathrm{g} / \mathrm{ml}$ of ICL extracts were added to the cells and the control cells were left untreated. Twenty four hour post exposure to ICL extract, the untreated control and treated cells were washed twice with $1 \mathrm{x}$ PBS and fixed with prechilled $70 \%$ ethanol for $24 \mathrm{~h}$ at $4^{\circ} \mathrm{C}$. These cells were again washed twice with 1x PBS, incubated with $100 \mu \mathrm{g} /$ $\mathrm{ml}$ of DNase free-RNase-A at $37^{\circ} \mathrm{C}$ for $1 \mathrm{~h}$ and stained for 30 minutes with $50 \mu \mathrm{g} / \mathrm{ml}$ of propidium iodide in $0.1 \%$ Trition X-100 plus $0.1 \mathrm{mM}$ EDTA at room temperature (Nair et al., 2014). The cells were then analyzed for cell cycle distribution using BD FACS Calibur flow cytometer (Becton Dickinson, San Jose, CA, USA). The relative proportions of cells at the various phases of the cell cycle were estimated based on their DNA contents and it was calculated using an inbuilt CellQuest Pro software.

\section{Clonogenic assay}

Clonogenic assay was performed as described previously (Franken et al., 2006). The SCC-9 cells were harvested by trypsinization from a 70 to $80 \%$ confluent monolayer, washed and resuspended in DMEM medium. These cells were seeded at a density of $5 \times 10^{3}$ cells per 35 mm dish containing DMEM with $10 \% \mathrm{FBS}$, and incubated at $37^{\circ} \mathrm{C}$ in a humidified incubator for $24 \mathrm{~h}$. The cells were then treated either with $80,160,320$, and $640 \mu \mathrm{g} / \mathrm{ml}$ of ICL extract or with $1 \%$ DMSO vehicle and incubated for an additional $24 \mathrm{~h}$. At the end of the incubation period the media was replaced with fresh DMEM containing $10 \%$ FBS, and the medium was renewed once in every 5 days. After 21 days, the media was removed and the cells were washed with 1x PBS, fixed with $3.7 \%$ paraformaldehyde in $1 \times$ PBS, and stained with $0.25 \%$ crystal violet for 30 min at room temperature. The colonies of cells were washed in $1 x$ PBS to remove excess dye and air dried. The number of colonies containing at least 50 cells / colony was counted using a Stereomicroscope (Motic, Hong Kong) to determine the plating efficiency (PE). The ratio of PE between treated and untreated cells represented the surviving fractions (SF) of colony forming cells. The clonogenic ability of the untreated control cells were taken as $100 \%$. The data were collected from three independent experiments and the mean $\pm \mathrm{SD}$ were calculated.

\section{DNA fragmentation assay}

The SCC- 9 cells were seeded in cell culture plates and treated with 320 and $640 \mu \mathrm{g} / \mathrm{ml} \mathrm{ICL}$ extracts for $24 \mathrm{~h}$ at $37^{\circ} \mathrm{C}$ in a humidified atmosphere of $5 \% \mathrm{CO}_{2}$ as described in section 2.3 of Materials and Methods. The untreated control and the treated cells were collected and lysed with $1.0 \mathrm{ml}$ of lysis buffer and treated with DNase freeRNase-A $(50 \mu \mathrm{g} / \mathrm{ml})$ in the presence of $0.1 \%$ SDS for $1 \mathrm{~h}$ at $37^{\circ} \mathrm{C}$. The lysis buffer consisted of $100 \mathrm{mM} \mathrm{NaCl}, 10 \mathrm{mM}$ Tris- $\mathrm{HCl}$ (pH 8.0), 25 mM EDTA, $0.5 \%$ sodium dodecyl sulphate (SDS) and $200 \mu \mathrm{g} / \mathrm{ml}$ of DNase-free proteinase K. The DNAs were precipitated with $100 \%$ ethanol, washed and resuspended in TE (Tris-Hcl-EDTA) buffer (Mitra et al., 2012). Three micrograms of the DNAs from control and treated samples were separated electrophoretically in a $1.2 \%$ agarose gel containing $0.001 \%$ ethidium bromide. The bands were visualized and photographed using a gel documentation system (Syngene, Cambridge, UK).

\section{Statistical analyses}

Data for MTT, clonogenicity and cell cycle were expressed as mean \pm standard deviation (SD). Nonlinear regression analysis was employed to obtain dose-response curve on a logarithmic scale and to determine relative $\mathrm{IC}_{50}$ value. The statistical comparison to determine significant differences between treated and control group was performed by one-way or two-way ANOVA followed by Dunnett's post-hoc test. All statistical analysis was 
performed using Graph Pad Prism (Graph Pad Software Inc. San Diego, USA). The differences between the control and treated groups were considered significant when $\mathrm{p}<0.05$.

\section{Results}

Effect of ICL extract treatment on the morphology of SCC-9 cells

The control untreated SCC-9 cells showed epithelial like morphological characteristics (Figure 1, left panel). The ICL treated SCC-9 cells showed significant changes visually as they lost the characteristic epithelial-like morphology. The treated cells also lost contact with adjacent cells, considerably shrank in size and attained rounded shape (Figure 1, center and right panel). The morphological changes were well pronounced when the cells were exposed to ICL extracts at the concentrations of 320 and $640 \mu \mathrm{g} / \mathrm{ml}$. No significant change in the

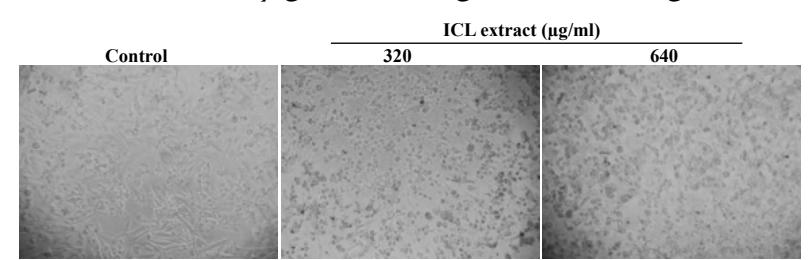

Figure 1. Morphology of SCC-9 Cells Upon Treatment with ICL Extract. Morphological features of the cells were visualized using light microscope and photographed at 10X magnification. The left panel shows control cells with an epithelial-like morphology typical of SCC-9 cells. The centre and right panel show cells after $24 \mathrm{~h}$ treatment with 320 and $640 \mu \mathrm{g} /$ $\mathrm{ml}$ ICL extract respectively. Pronounced morphological changes - loss of contact with adjacent cells, considerable shrinkage in size and rounded shape can be observed

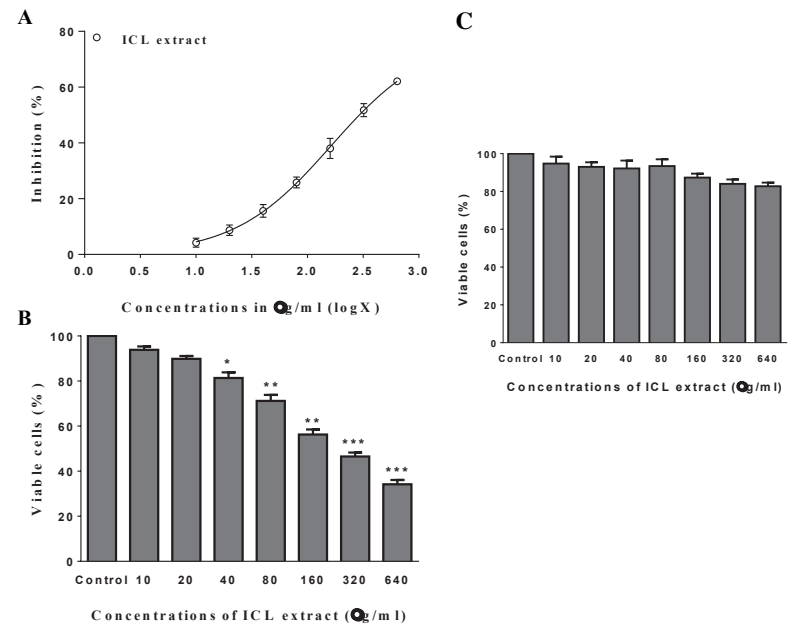

Figure 2. Cytotoxicity of ICL Extract on Human Tongue Squamous Cell Carcinoma (SCC-9) and Fibroblast Cells (NIH/3T3) Determined by MTT Assay.

(A) Dose-dependent growth inhibitory effect were observed in ICL extract treated SCC-9 cell line with an $\mathrm{IC}_{50}$ of $139.8 \mu \mathrm{g} / \mathrm{ml}$. Inhibitory effect was not observed in the control (1\% DMSO vehicle) cells. (B) The bars represent percent growth inhibition of SCC-9 cells \pm SD of triplicate experiments. When compared to the control the results were statistically significant $(* \mathrm{p}<0.05$, $* * \mathrm{p}<0.005, * * * \mathrm{p}<0.0008)$. (C) The bars represent percent growth inhibition of NIH/3T3 cells \pm SD of triplicate experiments. No significant growth inhibition was observed morphology was found when these cells were treated with lower concentrations of ICL extracts. The NIH/3T3 cells which were used as an additional control showed little morphological changes when treated with high concentrations of ICL extracts (data not shown).

\section{Cytotoxic effect of ICL extract on SCC-9 cells}

The relative $\mathrm{IC}_{50}$ of the ICL extract was found to be $139.8 \mu \mathrm{g} / \mathrm{ml}$ (Figure 2A). The MTT assay revealed a dose dependent inhibition of SCC-9 cell proliferation when these cells were treated with various concentrations of ICL extracts for $24 \mathrm{~h}$ (Figure 2B). Treatment with lower concentrations of 10 to $40 \mu \mathrm{g} / \mathrm{ml}$ of ICL extracts resulted in less than $20 \%$ inhibition of SCC-9 cell proliferation. Moderate concentrations of 80 and $120 \mu \mathrm{g} / \mathrm{ml}$ of the ICL extract caused only a 20 to $25 \%$ of inhibition of cell proliferation. At the concentrations of $320 \mu \mathrm{g} / \mathrm{ml}$ and $640 \mu \mathrm{g} / \mathrm{ml}$ the ICL extract inhibited SCC-9 cell proliferation by approximately $50 \%$ and $60 \%$ respectively. No such inhibition of cell proliferation was found when the NIH/3T3 cells were treated with the same higher concentrations of ICL extracts (Figure 2C). The observed cytotoxicity of the ICL extract was specific only to the oral squamous cell carcinoma cell, SCC-9, and not to the control NIH/3T3 fibroblast cells (Figure 2A, 2B, 2C).

Effect of ICL extract on clonogenic potential of SCC-9 cells

Higher proportion of Surviving Fractions (SFs) of 0.8 and 0.7 were observed when the SCC- 9 cells were treated for $24 \mathrm{~h}$ with moderate concentrations of $80 \mu \mathrm{g} /$

A

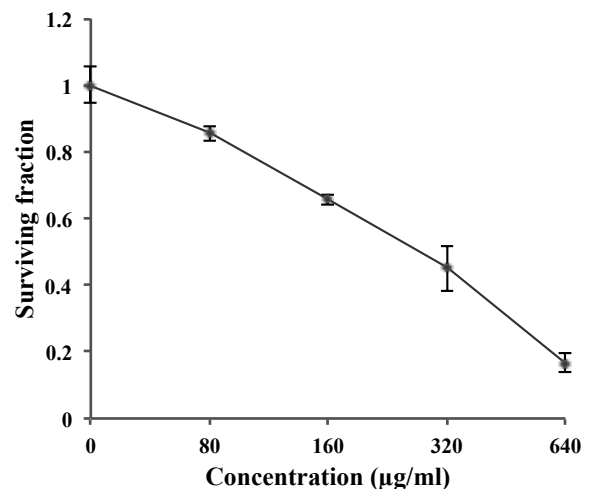

B

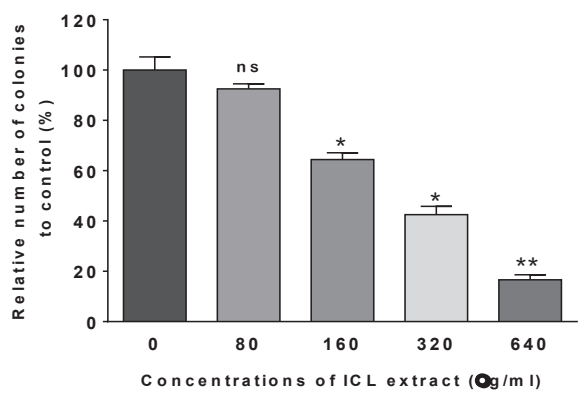

Figure 3. Effect of ICL Extract on Clonogenic Ability of SCC-9 Cells. (A) Survival curve with mean values \pm SD are presented. (B) Quantitative bar-graph representing the number of colonies ( $>50$ cells / colony) as percentage relative to the untreated control, mean \pm SD from three independent experiments. When compared to the control the results were statistically significant $(* \mathrm{p}<0.05, * * \mathrm{p}<0.005)$ 


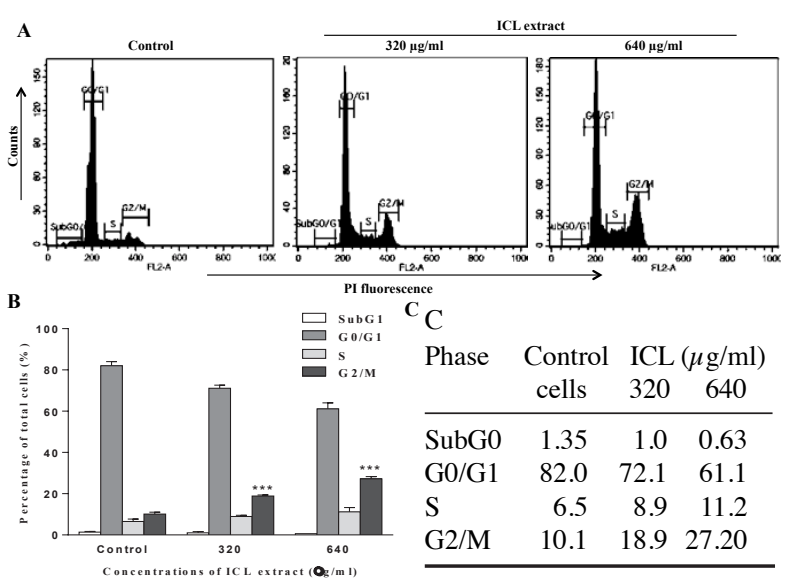

Figure 4. Flow Cytometric Analysis of ICL Extract Treated SCC-9 Cells at Various Stages of the Cell Cycle. (A) Left panel - untreated control; Middle panel- $320 \mu \mathrm{g} /$ $\mathrm{ml}$ ICL extract treated cells; Right panel - $640 \mu \mathrm{g} / \mathrm{ml}$ ICL extract treated cells. (B) The percentage of cells in phases of the cell cycle in both treated and control as indicated. The results are the mean \pm SD of data from three independent experiments. When compared to control the results were statistically significant $(* * * p<0.0001)$. (C) Table showing the percentage of cells in the different phases of the cell cycle in treated and control SCC-9 cells

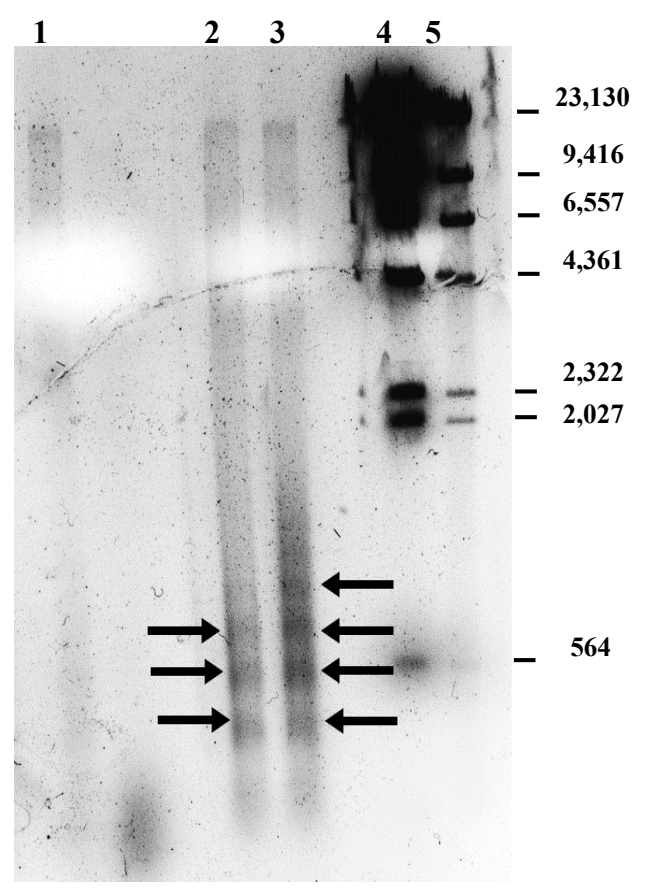

Figure 5. DNA Fragmentation Assay. Lane 1, DNA from the untreated control SCC-9 cells; Lane 2, DNA from SCC-9 cells treated with $320 \mu \mathrm{g} / \mathrm{ml}$ of ICL extract; Lane 3, DNA from SCC-9 cells treated with $640 \mu \mathrm{g} / \mathrm{ml}$ of ICL extract; Lane 4, 0.5 $\mu \mathrm{g}$ of lambda DNA Hind III digest; Lane 5, $0.2 \mu \mathrm{g}$ of lambda DNA, Hind III digest. The arrows indicate the bands in the DNA ladder. The molecular weights are marked on the right

$\mathrm{ml}$ and $160 \mu \mathrm{g} / \mathrm{ml}$ of ICL extracts respectively. However, significantly reduced number of SFs of 0.5 and 0.15 were found when these cells were treated with higher concentrations of $320 \mu \mathrm{g} / \mathrm{ml}$ and $640 \mu \mathrm{g} / \mathrm{ml}$ of ICL extracts respectively (Figure 3A). The untreated, control SCC-9 cells had the maximum clonogenic ability of $100 \%$. The clonogenic ability was found to be more than $90 \%$ when these cells were treated with a moderate concentration of $80 \mu \mathrm{g} / \mathrm{ml}$ of ICL extract. Approximately $70 \%$ of the SCC-9 cells retained their clonogenic ability after the treatment with a moderate concentration of $160 \mu \mathrm{g} / \mathrm{ml}$. At higher concentrations of $320 \mu \mathrm{g} / \mathrm{ml}$ and $640 \mu \mathrm{g} / \mathrm{ml}$ the clonogenic ability was significantly reduced to $50 \%$ and $15 \%$ respectively (Figure $3 \mathrm{~B}$ ). The reduced SFs and clonogenecity in the ICL extract treated SCC-9 cells as compared to the untreated control cells were statistically significant with a value of $* * \mathrm{p}<0.001$.

\section{Effect of ICL extract on the SCC-9 cell cycle}

A small percentage of $10.1 \%$ of the total number of the untreated control SCC-9 cells were found in the G2/M phase of the cell cycle. However after $24 \mathrm{~h}$ of treatment with $320 \mu \mathrm{g} / \mathrm{ml}$ and $640 \mu \mathrm{g} / \mathrm{ml}$ of ICL extracts a higher fraction of $18.91 \%$ and $27.20 \%$ were found in $\mathrm{G} 2 / \mathrm{M}$ phase respectively (Figure 4A). Simultaneously, the percentage of total fraction of cells at the G0/G1 phase decreased to 72.14 and $61.09 \%$ when they were treated with $320 \mu \mathrm{g} /$ $\mathrm{ml}$ and $640 \mu \mathrm{g} / \mathrm{ml}$ respectively. However the untreated control had more than $80 \%$ cells in G0/G1 phase (Figure $4 \mathrm{~B}, 4 \mathrm{C})$. The differences observed in the number of cells at the G0/G1 and G2/M phases in the treated SCC-9 cells as compared to the untreated control cells were statistically significant with a $* * * \mathrm{p}<0.0001$.

\section{Effect of ICL extract treatment on the DNA integrity and DNA laddering}

A large proportion of the DNA samples from the untreated control SCC- 9 cells barely entered the agarose gel and there was no DNA fragmentation in the form of a ladder in these control samples. However, almost all of the DNA samples from the cells treated for $24 \mathrm{~h}$ with $320 \mu \mathrm{g} / \mathrm{ml}$ or $640 \mu \mathrm{g} / \mathrm{ml}$ of ICL extracts freely entered the gel. The DNA samples from these treated cells also showed apoptosis specific DNA ladder and the size of the bands in these ladders ranged from 200 to 1,800 base pairs (Figure 5).

\section{Discussion}

Phytocompounds are emerging as one of the promising alternative therapeutics for treatment and management of human cancers because of the systemic toxicity caused by the existing therapeutic agents as well as the emergence of treatment resistant cancer cells. Extracts of I. cylindrica have diverse pharmacological activities and more importantly they have no side effects or systemic toxicity in humans. Oral administration of this formulation to patients caused no harm or side effects such as burning sensation to the digestive system or diarrhea (Jayalakshmi et al, 2010; Parvathy et al, 2012).

Many anticancer drugs extracted from medicinal plants exert their cytotoxic effects through a common mechanism. In general, these phyto compounds seem to invariably induce cell cycle arrest and cause cell death by apoptosis (Xavier et al., 2009; Tsai et al., 2012). Likewise, the extracts from I. cylindrica also inhibited cell proliferation and induced apoptosis in various human cancer cell lines (Kuete et al., 2011; Kuete et al., 2013). 
Phytoderivatives from cranberry and grape seed extracts as well as a plant derived compound, proanthocyanidin caused morphological changes in oral squamous cell carcinoma (King et al., 2007; Chatelain et al., 2011). Data from the present study show similar morphological changes in the ICL extract treated SCC-9 squamous cell carcinoma cell line. It is important to note that these changes were found only when these cells were treated with higher concentrations of the extract which is indicative of concentration dependent effect of ICL extract on SCC-9 cells (Figure 1). MTT assay was performed to assess the cytotoxic potential of ICL extracts, as only mitochondrial dehydrogenase formed in viable cells are able to reduce tetrazolium salt (MTT) into an insoluble formazan product (Mosmann, 1983). Data from the MTT assay further confirms the cytotoxicity and also supports the concentration dependent cytotoxic effect of ICL extract on SCC-9 cells (Figure 2A, 2B). The observed cytotoxic effect of ICL extract only to the SCC-9 squamous cell carcinoma cells and not to the NIH/3T3 normal fibroblast cells indicates that the cytotoxicity is restricted only to the cancer cells and not to the normal cells (Figure 2C). Our data on the cancer cell specific cytotoxicity of ICL extract is in agreement with the previous reports which have demonstrated cytotoxicity of I. cylindrica extract in vitro on other cancer cell lines (Kuete et al., 2011; Kuete et al., 2013).

Clonogenecity is one of the important characteristics of cancer cells. The clonogenic assay is one of the standard methods for measuring the anti-clonogenic effect of cytotoxic agents in vitro (Katz et al., 2008). It is widely recognized that any substance that inhibits clonogenic progression of tumor cells could be considered as a potential anticancer therapeutic agent (Katz et al., 2008; Rafehi et al., 2011). Therefore, the effect of ICL extract on the colony formation ability was assessed by clonogenic assay. Our data from the clonogenic survival assay show that the exposure of SCC-9 cells to higher concentrations of ICL extract significantly inhibited the clonogenic potential of these cells in vitro (Figure 3A,3B). The observed anti-clonogenic activity of the ICL extract is indicative of its potential use as anticancer therapeutic agent especially to treat/manage human oral cancers.

Many anticancer agents arrest cancer cell division at various stages of the cell cycle. Genistein, a natural isoflavinoid caused cell cycle arrest in MCF-7 human breast cancer cell line in vitro in a dose dependent manner. At higher concentrations genistein caused persistent cell cycle arrest at G2/M phase (Pagliacci et al., 1994). Another plant product "Ruta" showed anticancer activity against colon cancer cell line COLO 205 and it caused cell death and cell cycle arrest at G2/M phase (Arora and Tandon, 2015). The cytotoxic and anti-clonogenic effects of ICL extracts on SCC-9 cells were further examined by evaluating the cell cycle distribution post treatment.Data from the present study showed that the ICL extracts from the plant I. cylindrica caused cell death and cell cycle arrest at $\mathrm{G} 2 / \mathrm{M}$ phase (Figure $4 \mathrm{~A}, 4 \mathrm{~B}, 4 \mathrm{C}$ ).

Integrity of DNA is a prerequisite for the survival and for the maintenance of infinite proliferative potential of cancer cells and many phytocompounds with anticancer property disrupt this integrity (Tsai et al., 2012; Arora and Tandon, 2015). Presence of a characteristic DNA ladder in the cancer cells post anticancer treatment is a hallmark of apoptotic cell death (Wyllie, 1980; Hengartner, 2000). Presence of such a DNA ladder in the ICL extract treated SCC-9 cells as compared to the untreated control cells indicates that the observed cell death was caused by apoptosis (Figure5).

The change in morphology, cytotoxicity, anticlonogenic activity, cell cycle arrest and DNA fragmentation observed in the ICL extract treated SCC9 squamous cell carcinoma cells as compared to the untreated control show that these effects were caused by the ICL extract treatment. The characteristic cell cycle arrest at G2/M and the DNA fragmentation caused by ICL extract indicates that the cell death was caused by apoptosis and not by generalized cellular toxicity. It is important to note that the ICL extract induced cell death only at higher concentrations and further purification and fractionation could yield active compounds that are effective at lower doses.

Thus, the ICL extract obtained from I. cylindrica can be developed into a potential anticancer therapeutic agent to manage/treat human oral cancers. Biochemical analysis of the roots of I. cylindrica indicated the presence of glycosides, alkaloids and flavonoids (Amin et al., 2009). Our preliminary biochemical analysis show the presence of similar compounds in the I. cylindrica leaf extract as well (data not shown). It would be interesting to evaluate if these constituents either individually or in various combinations and concentrations could act in synergy to produce anticancer activity.

In conclusion, This is the first report revealing the anticancer activity of the methanol extracts from the leaves of I. cylindrica on oral cancer cell lines. The anticancer activity of the ICL extract was specific for the human tongue squamous cell carcinoma, SCC-9, cells and not to the NIH/3T3 fibroblast cells. It is important to note that the ICL extract caused cell death in SCC-9 cancer cells by reducing their clonogenecity, generating DNA fragmentation and by inducing apoptosis. Abundant quantities of I. cylindrica grow in the wild in many parts of the world and they can also be easily cultivated in any muddy ground space around the scientific laboratories as they demand little care. Currently, cancer research is concentrated towards combinatorial therapies where multiple units of the cancer cell survival pathways could be disrupted simultaneously. Such strategies would help to reduce cancer recurrence or even completely eliminate all cancer cells; thereby improve the quality of life of the cancer patients post anticancer treatment regimen. In this regard the present study opens up a new avenue towards development of novel, cost effective, anticancer therapeutic agent from an abundant plant source, $I$. cylindrica, whose products already have been proven to have no undesirable side effects or systemic toxicity in human. Overall data from the present study opens up novel perspectives and pharmacological avenues as a promising modality for effective treatment and management of human oral cancers. 


\section{Acknowledgements}

This work was supported by the grant from University Grants Commission (UGC) - Dr. D.S. Kothari postdoctoral fellowship scheme awarded to Dr. Rohini Keshava (Ref. no. F.4-2/2006 (BSR)/BL/13-14/0131), under the mentorship of Prof. Ananthanarayana S.R. We thank Dr. M. D. Rajanna, Professor and Curator and Dr. Shringesh at the Botanical garden, University of Agricultural Sciences, G.K.V.K campus, Bangalore, Karnataka, India, for identifying and authenticating the I. cylindrica plant. The authors wish to acknowledge the Chairman, Department of Life Sciences, Bangalore University for moral support and encouragement. We also wish to thank Dr. Yogisha Shivanna, Director, Skanda Life Sciences Pvt. Ltd., for helpful discussion and suggestions. The assistance of Mr. Manohar Nanjappa, Scientist at Skanda Life Sciences Pvt. Ltd is gratefully acknowledged.

\section{References}

Amin AR, Kucuk O, Khuri FR, Shin DM, (2009). Perspectives for cancer prevention with natural compounds. J Clin Oncol, 27, 2712-25.

Anantharaman D, Gheit T, Waterboer T, et al (2013). Human papillomavirus infections and upper aero-digestive tract cancers: the ARCAGE study. J Natl Cancer Inst, 105, $536-45$.

Arora S, Tandon S (2015). DNA fragmentation and cell cycle arrest: a hallmark of apoptosis induced by Ruta graveolens in human colon cancer cells. Homeopathy, 104, 36-47.

Ayurvedic Pharmacopoeia of India, Part 1, Vol. V, First Edition, (2006). Ministry of health and family welfare, department of ayurveda, yoga and naturopathy, unani, siddha and homoeopathy (AYUSH), Government of India, New Delhi.

Chatelain K, Phippen S, McCabe J, et al (2011). Cranberry and grape seed extracts inhibit the proliferative phenotype of oral squamous cell carcinomas. Evid Based Complement Alternat Med, 2011, 467691.

Chen M, Huang J, Yang X, et al (2012). Serum starvation induced cell cycle synchronization facilitates human somatic cells reprogramming. PLoS One, 7, 28203.

de Camargo-Cancela M, Voti L, Guerra-Yi M, et al (2010). Oral cavity cancer in developed and in developing countries: population-based incidence. Head Neck, 32, 357-67.

Dikshit R, Gupta PC, Ramasundarahettige C, et al (2012). Cancer mortality in India: a nationally representative survey. Lancet, 379, 1807-16.

Doan, D.D., Nguyen, N.H., Doan, H.K., Nguyen, T.L., Phan, T.S., van Dau, N., Grabe, M.,

Johansson R, Lindgren G, Stjernstrom NE, (1992). Studies on the individual and combined diuretic effects of four Vietnamese traditional herbal remedies (Zea mays, Imperata cylindrica, Plantago major and Orthosiphon stamineus). $J$ Ethnopharmacol, 36, 225-31.

Ferlay J SI, Ervik M, Dikshit R, et al (2013). GLOBOCAN 2012 v1 .0, Cancer Incidence and Mortality Worldwide. [Online]. lyon, france: international agency for research on cancer.

Forman D, Bray F, Brewster DH, et al (2014). Cancer incidence in five continents. Vol X [Online]. Lyon, France: IARC scientific publication, No 164.

Franken NA, Rodermond HM, Stap J, et al (2006). Clonogenic assay of cells in vitro. Nat Protoc, 1, 2315-9.

Fulda S (2010). Modulation of apoptosis by natural products for cancer therapy. Planta Med, 76, 1075-9.
Guruprasad KP, Mascarenhas R, Gopinath PM, et al (2010). Studies on Brahma rasayana in male swiss albino mice: chromosomal aberrations and sperm abnormalities. $J$ Ayurveda Integr Med, 1, 40-4.

Harborne JB (1998). Phytochemical methods- a guide to modern techniques of plant analysis, springer science \& business media.

Hengartner MO (2000). The biochemistry of apoptosis. Nature, 407, 770-6.

IARC. (2012). Personal Habits and Indoor Combustions [Online]. Lyon, France: IARC.

Jayalakshmi S, Patra A, Lal VK, Ghosh, A K (2010). Pharmacognostical standardization of roots of Imperata cylindrica Linn (Poaceae). J Pharm Sci Res, 2, 5.

Katz D, Ito E, Lau KS, et al (2008). Increased efficiency for performing colony formation assays in 96-well plates: novel applications to combination therapies and high-throughput screening. Biotechniques, 44, ix-xiv.

King M, Chatelain K, Farris D, et al (2007). Oral squamous cell carcinoma proliferative phenotype is modulated by proanthocyanidins: a potential prevention and treatment alternative for oral cancer. BMC Complement Altern Med, 7, 22 .

Krishna Rao SV, Mejia G, Roberts-Thomson K, et al (2013). Epidemiology of oral cancer in Asia in the past decade--an update (2000-2012). Asian Pac J Cancer Prev, 14, 5567-77.

Kuete V, Krusche B, Youns M, et al (2011). Cytotoxicity of some Cameroonian spices and selected medicinal plant extracts. J Ethnopharmacol, 134, 803-12.

Kuete V, Sandjo LP, Wiench B, et al (2013). Cytotoxicity and modes of action of four Cameroonian dietary spices ethno-medically used to treat cancers: Echinops giganteus, Xylopia aethiopica, Imperata cylindrica and Piper capense. J Ethnopharmacol, 149, 245-53.

Mitra R, Devi BI, Gope ML, et al (2012). Sodium butyrate modulates $\mathrm{pRb}$ phosphorylation and induces cell death in human vestibular schwannomas in vitro. Indian J Exp Biol, 50, 19-27.

More Y, D'Cruz AK (2013). Oral cancer: review of current management strategies. Natl Med J India, 26, 152-8.

Mosmann T (1983). Rapid colorimetric assay for cellular growth and survival: application to proliferation and cytotoxicity assays. J Immunol Methods, 65, 55-63.

Nair SV, Hettihewa M, Rupasinghe HP (2014). Apoptotic and inhibitory effects on cell proliferation of hepatocellular carcinoma HepG2 cells by methanol leaf extract of Costus speciosus. Biomed Res Int , 2014, 637098.

Newman DJ, Cragg GM (2007). Natural products as sources of new drugs over the last 25 years. J Nat Prod, 70, 461-77.

Pagliacci MC, Smacchia M, Migliorati G, et al (1994). Growthinhibitory effects of the natural phyto-oestrogen genistein in MCF-7 human breast cancer cells. Eur J Cancer, 30, 1675-82.

Parvathy NG, Padma R, Renjith V, Rahate KP, Saranya TS (2012). Phytochemical screening and anthelmintic activity of methanolic extract of Imperata cylindrica. Int J Pharm Pharmaceut Sci, 4, 3.

Pinilla V, Luu B (1999). Isolation and partial characterization of immunostimulating polysaccharides from Imperata cylindrica. Planta Med, 65, 549-52.

Pragya T, Verma U, Singh R, Joshi PK, Rout OP, (2015). Rasayana' herbs used in ayurveda -a review. World $J$ Pharmacy Pharmaceutical Sciences, 8.

Qi F, Li A, Inagaki Y, et al (2010). Chinese herbal medicines as adjuvant treatment during chemo- or radio-therapy for cancer. Biosci Trends, 4, 297-307.

Rafehi H, Orlowski C, Georgiadis GT, et al (2011). Clonogenic 
Rohini Keshava et al

assay: adherent cells. J Vis Exp.

Sankaranarayanan R, Ramadas K, Thomas G, et al (2005). Effect of screening on oral cancer mortality in Kerala, India: a cluster-randomised controlled trial. Lancet, 365, 1927-33.

Shah NT, Pandya TN, Sharma PP, Patel BR, Acharya R, (2012). Mootrala Karma of Kusha [Imperata cylindrica Beauv.] and Darbha [Desmostachya bipinnata Stapf.] - A comparative study. Ayu, 33, 387-90.

Saraswathy M, Gong S (2013). Different strategies to overcome multidrug resistance in cancer. Biotechnol Adv, 31, 1397407.

Sushama B, Nishteswar K (2014). Review of anti-oxidant herbal drugs w.s.r to madhuraskandha (charakasamhita). Int $J$ Ayurvedic Herbal Med, 4, 1480-93.

Thorat RV, Panse NS, Budukh AM, et al (2009). Prevalence of tobacco use and tobacco-dependent cancers in males in the rural cancer registry population at Barshi, India. Asian Pac J Cancer Prev, 10, 1167-70.

Tsai YL, Chiu CC, Yi-Fu Chen J, et al (2012). Cytotoxic effects of Echinacea purpurea flower extracts and cichoric acid on human colon cancer cells through induction of apoptosis. $J$ Ethnopharmacol, 143, 914-9.

Wyllie AH (1980). Glucocorticoid-induced thymocyte apoptosis is associated with endogenous endonuclease activation. Nature, 284, 555-6.

Xavier CP, Lima CF, Preto A, et al (2009). Luteolin, quercetin and ursolic acid are potent inhibitors of proliferation and inducers of apoptosis in both KRAS and BRAF mutated human colorectal cancer cells. Cancer Lett, 281, 162-70.

Yoon JS, Lee MK, Sung SH, et al (2006). Neuroprotective 2-(2-phenylethyl)chromones of Imperata cylindrica. J Nat Prod, 69, 290-1. 